\title{
Education
}

\section{Enterprise Projects: Experiential Learning in Applied Entomology}

\author{
Mark D. Shelton
}

D URING 1924, when jobs for college students were difficult to find in San Luis Obispo, Calif., a group of entrepreneurial students at the California Polytechnic School negotiated an $\$ 80$ bank loan from a local lender to raise chickens. Parents and college faculty cosigned the loan, and thus was born the Agricultural Enterprise Program.

Several years later, a student enterprise project bred a strain of chickens that won first place for three consecutive years at the National Laying Test in Modesto, Calif. Other successful projects followed. Local townspeople and faculty spouses often traveled to campus several times a week. The first stop was at the poultry unit for eggs; the next was across the street for flowers and, finally, to the campus dairy for milk and ice cream. Although the Enterprise Program began as a source of student income, it soon began contributing to the state agricultural industry and local economy and providing students an opportunity to produce agricultural commodities.

As the Enterprise Program grew, it became an integral part of the agricultural curriculum at the then Cal Poly State College, whose enabling legislation placed much emphasis on technical and professional programs such as agriculture and engineering. A campus foundation took over fiscal management of Enterprise Projects in 1943. The foundation's function then, as now, was to provide start-up funds to students for seed, fertilizer, equipment, and animals and then share in the net profits (if any) from the sale of project commodities. These commodities are marketed by students through a local farmer's market as well as traditional produce and livestock brokers. Most local agricultural producers are supportive of the projects, although students have sometimes caused problems by underselling their competitors. Money-making projects subsidize those that lose money, so each project has a financial "safety net." Students may earn elective credit for participation in an enterprise, and supervision of these projects is factored into the teaching loads of participating faculty members. From the original

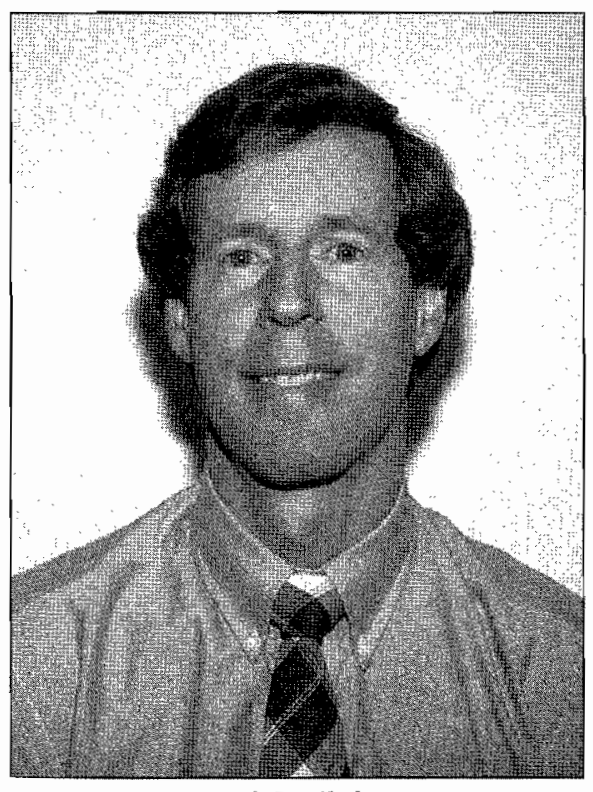

Mark D. Shelton

poultry project in 1924, the Enterprise Program has grown to include cut flowers, fruit, vegetable and grain crops, livestock and dairy products, thoroughbred horse breeding, and Christmas trees, among others. Students from virtually all academic majors and personal backgrounds are involved in projects. Two Enterprise Projects in applied entomology are currently available through the Crop Science Department at Cal Poly. They exemplify the "learn by doing” philosophy of our enterprise system and have stimulated considerable student interest in entomology.

During the 1960s and 1970s, Ralph Vorhies maintained honeybee: colonies on campus to support his apiculture course. When Vorhies retired in 1980, Sherman Phillips (now at Texas Tech University) started the Beekeeping Enterprise Project, in which students managed the colonies under his supervision. Since 1982, I have directed this project and expanded student responsibilities to include antibiotic treatments, honey extraction and sales, requeening, and participation in commercial almond pollination.

A diverse group of students is attracted to the Beekeeping Enterprise Project (Table 1). Several former Peace Corps volunteers have participated in this enterprise project after gaining beekeeping experience overseas, and three participantshave subsequently worked on apicultural consultancies with Peace Corps and U.S. Agency for International Development. The interactions between students of diverse ethnic, cultural, and academic backgrounds have always been a strength of enterprise projects. Many students with no background in agriculture or entomology become enthusiastic for these subjects following project participation. Because of their interest, enrollment in the apiculture course has doubled in the past nine years.

A second applied entomology enterprise project (the Plant Protection Enterprise) was started by A. C. Crabb and JoAnn Wheatley in 1990. This project involves students in pest scouting and management under the supervision of faculty holding Pest Control Advisor licenses. Students monitor pest and beneficial arthropods in campus orchard and vegetable crops, then

Table 1. Students on Beekeeping Enterprise Projects, 1989-1992

\begin{tabular}{|c|c|c|c|}
\hline Project year & No. students & Academic majors & Countries of origin \\
\hline $1989-1990$ & 12 & $\begin{array}{l}\text { Crop science, animal science, ornamental } \\
\text { horticulture, history }\end{array}$ & $\begin{array}{l}\text { United States, } \\
\text { Israel, Kuwait, } \\
\text { Egypt, Mexico }\end{array}$ \\
\hline 1990-1991 & 13 & $\begin{array}{l}\text { Agribusiness, biology, business, computer } \\
\text { science, dairy science, engineering, political } \\
\text { science }\end{array}$ & $\begin{array}{l}\text { United States, } \\
\text { Australia, Lesotho, } \\
\text { Japan, Zimbabwe }\end{array}$ \\
\hline 1991-1992 & 16 & $\begin{array}{l}\text { Agribusiness, agricultural engineering, ani- } \\
\text { mal science, computer science, engineering, } \\
\text { fruit science, ornamental horticulture }\end{array}$ & $\begin{array}{l}\text { United States, } \\
\text { Spain }\end{array}$ \\
\hline
\end{tabular}


report their findings to the project advisors. Project students also gain experience in release of parasitoids and predators, writing pesticide recommendations, applying pesticides, and complying with numerous pesticide regulations. Several students have obtained pesticide applicator's licenses as a result of their participation in this project. Other students have attended professional seminars for pest control advisors to broaden their pest management knowledge. The experiences gained on this project certainly teach students applied entomology better than classroom instruction alone.

Enterprise projects are complementary to traditional education in entomology. Because enterprise projects are offered on a credit-no credit basis, they appeal to students with no prior agricultural or entomological background. Their hands-on nature gives students a chance to learn by working in small groups directly with faculty members. This type of educational experience is normally reserved for graduate students. As enrollment in entomology courses has declined in recent years, many entomology programs have merged with departments representing other agricultural or biological sciences. This has reduced the visibility of entomology on many campuses and threatens to limit the numbers of students attracted to the discipline further. Experiential projects in applied entomology such as those described here attract a diverse group of students, many of whom pursue formal entomological coursework as a result of project participation.

Mark D. Shelton is an entomology professor in the Crop Science Department at California Polytechnic State University (Cal Poly), San Luis Obispo, Calif. 